\title{
Faktor-Faktor yang Memengaruhi Pemilihan Karir sebagai Konsultan Pajak
}

\author{
I Gusti Ayu Agustia Arini ${ }^{1}$ \\ Fakultas Ekonomi dan Bisnis \\ Universitas Udayana, Indonesia
}

\author{
Naniek Noviari ${ }^{2}$ \\ Fakultas Ekonomi dan Bisnis \\ Universitas Udayana, Indonesia
}

\begin{abstract}
Surel : agustiaarini111@gmail.com
ABSTRAK

Penelitian ini bertujuan untuk mengetahui apakah pelatihan professional, pengakuan professional, lingkungan kerja, peran gender, serta pengaruh orang tua berpengaruh pada pemilihan karir sebagai konsultan pajak. Teori yang digunakan dalam penelitian ini theory of planned behaviour (TPB). Populasi dalam penelitian ini karyawan konsultan pajak LMATS Consulting dan jumlah sampel sebanyak 60 karyawan dengan menggunakan teknik pengumpulan data metode kuesioner dengan purposive sampling yaitu karyawan divisi akutansi atau divisi pajak, yang telah bekerja minimal 1 tahun dengan pendidikan terakhir D3. Lokasi penelitian di kantor Konsultan Pajak LMATS Consulting. Hasil penelitian ini didapat bahwa pelatihan professional, pengakuan professional, lingkungan kerja, gender, serta pengaruh orang tua berpengaruh positif dan signifikan terhadap pemilihan karir sebagai konsultan pajak di kantor konsultan pajak LMATS Consulting.
\end{abstract}

Kata Kunci: Karir; Konsultan Pajak; Karyawan.

\section{Factors That Impact Career Selection as a Tax Consultant}

\section{ABSTRACT}

This study aims to determine whether professional training, professional recognition, work environment, gender roles, and the influence of parents influence career choices as tax consultants. The theory used in this research is Theory of Planned Behavior (TPB). The population in this study were employees of the LMATS Consulting tax consultant and the total sample was 60 employees using the questionnaire method data collection technique with purposive sampling, namely employees of the accounting division or tax division, who have worked at least 1 year with the latest education of D3. Research location at the LMATS Consulting Tax Consultant office. The results of this study indicate that professional training, professional recognition, work environment, gender roles, and the influence of parents have a positive effect on career choices as a tax consultant in the LMATS Consulting tax consultant office.

Keywords: $\quad$ Career; Tax Consultant; Employee.

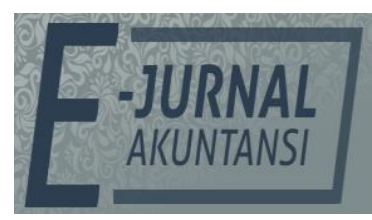

e-ISSN 2302-8556

Vol. 31 No. 1

Denpasar, Januari 2021

Hal. 246-258

DOI:

10.24843/EJA.2021.v31.i01.p19

PENGUTIPAN:

Arini, I G.A.A., \& Noviari,

N. (2021). Faktor-Faktor yang Memengaruhi

Pemilihan Karir sebagai

Konsultan Pajak. E-Jurnal

Akuntansi, 31(1), 246-258

RIWAYAT ARTIKEL:

Artikel Masuk:

2 September 2020

Artikel Diterima:

18 Januari 2021

Artikel dapat diakses : https://ojs.unud.ac.id/index.php/Akuntansi/index 


\section{PENDAHULUAN}

Keberadaan konsultan pajak akan semakin dibutuhkan terutama bagi Wajib Pajak yang memiliki tingkat kesibukan yang tinggi (www.klinikpajak.co.id, 2018). Ditjen Pajak akan terus membantu konsultan pajak melalui reformasi kebijakan, melakukan komunikasi, dan juga memberikan pedoman bagi perkembangan perpajakan itu sendiri. Hal tersebut akan dapat memberikan peluang kepada peminat yang ingin berkarir di bidang perpajakan (www.konsultanpajaksurabaya.com, 2018).

Perencanaan karir dipengaruhi oleh banyak faktor yang dapat membuat seseorang tertarik untuk memilih suatu karir terutama dalam bidang profesional seperti konsultan pajak. Faktor-faktor yang dapat membuat orang memilih berkarir sebagai konsultan pajak menurut Mulianto \& Mangoting (2014) salah satunya adalah pengakuan profesional yang dapat berpengaruh signifikan terhadap minat mahasiswa dalam pemilihan karir sebagai konsultan pajak. Pelatihan profesional merupakan suatu program yang dapat meningkatkan keahlian, pengetahuan serta dapat mengembangkan sikap dari karyawan. Adanya pelatihan profesional bagi karyawan perusahaan diharapkan dapat mencapai sasaran kerja yang di inginkan. Indriyarti (2018) menyatakan pemilihan berkarir dipengaruhi oleh pengakuan profesional. Penelitian serupa oleh Naminingsih \& Rahmayati (2019) menyatakan bahwa pelatihan profesional berpengaruh signifikan terhadap pemilihan karir akuntan publik yaitu pelatihan profesional merupakan suatu pembekalan dan peningkatan keahlian yang diberikan oleh suatu organisasi baik bagi calon karyawan ataupun karyawan tetap, dan hal tersebut akan memberikan manfaat secara langsung bagi karyawan dan calon karyawan. Profesi yang memiliki pelatihan profesional yang baik akan menjadi suatu daya tarik bagi profesi tersebut.

Minat seseorang untuk berperilaku atau memilih suatu karir berkaitan dengan Theory of planned behavior. Menurut Jogiyanto (2017) Theory of planned behavior menjelaskan bahwa perilaku seseorang dapat dipengaruhi oleh niat (intention), dan selanjutnya niat seseorang dapat dipengaruhi oleh faktor sikap, norma subjektif dan kontrol perilaku. Sikap (attitude) adalah perasaan positif atau negatif seseorang terhadap suatu perilaku atau obyek. Apabila seseorang memiliki sikap positif atau pandangan yang baik terhadap bidang karir perpajakan, maka mereka akan menilai bahwa pelatihan profesional dan pengakuan profesional dapat memberi manfaat yang baik bagi karir mereka, sehingga akan membentuk sikap positif pada keputusannya dalam pemilihan karir sebagai konsultan pajak. Keterkaitan variabel pelatihan profesional dan pengakuan profesional dengan Theory of planned behavior, yakni dalam teori TPB menyatakan bahwa niat berperilaku individu dimana dalam hal ini adalah minat seseorang dalam pemilihan karir menjadi konsultan pajak dipengaruhi oleh faktor sikap yakni sikap dalam menilai manfaat pelatihan dan pengakuan profesional. Sesuai dengan Theory of planned behavior, yaitu semakin positif sikap karyawan tersebut maka akan dapat memengaruhi keputusan karyawan dalam pemilihan karir yang tepat. Jadi apabila karyawan yang bekerja di kantor konsultan pajak LMATS Consulting menilai pelatihan profesional dapat memberi manfaat yang baik, maka akan membentuk sikap positif pada keputusannya dalam pemilihan karir. Melalui pelatihan profesional dapat meningkatkan 
keahlian, pengetahuan serta dapat mengembangkan sikap dari karyawan, sehingga minat pemilihan karir karyawan menjadi konsultan pajak semakin meningkat.

Penelitian Ari, et al., (2017) menyatakan bahwa pelatihan profesional berpengaruh positif dan signifikan terhadap minat mahasiswa dalam berkarir sebagai akuntan publik. Hasil berbeda diperoleh dalam penelitian Kuswidanti (2018) yang menyatakan bahwa pelatihan profesional tidak berpengaruh signifikan terhadap pemilihan karir menjadi akuntan publik. Hal ini memberikan informasi bahwa terdapat hasil penelitian terdahulu yang tidak konsisten antara pelatihan profesional terhadap pemilihan karir, sehingga perlu untuk dilakukan penelitian kembali pada variabel tersebut.

Faktor lain yang dapat memengaruhi pemilihan karir yaitu pengakuan profesional. Merdekawati \& Sulistyawati (2011) menyatakan pengakuan profesional merupakan pengakuan yang diberikan atas hal - hal yang berhubungan dengan prestasi seseorang. Pengakuan profesional dapat memengaruhi motivasi kerja karyawan, produktivitas dan kepuasan. Hal ini didukung oleh penelitian Mulianto \& Mangoting (2014) yang menyatakan pengakuan profesional berpengaruh signifikan terhadap pilihan karir mahasiswa akuntansi. Adanya kesempatan untuk berkembang, pengakuan apabila berprestasi dan adanya kenaikan jabatan memengaruhi minat mahasiswa untuk bekerja di kantor konsultan pajak. Penelitian Daulay (2016) juga menemukan hasil bahwa pengakuan profesional berpengaruh terhadap minat menjadi akuntan publik. Hasil tersebut menunjukkan bahwa pengakuan profesional dipertimbangkan oleh mahasiswa yang memilih profesi akuntan publik. Hal ini berarti bahwa memilih profesi, tidak hanya bertujuan mencari pengharapan finansial, tetapi juga ada keinginan untuk pengakuan berprestasi dan mengembangkan diri. Hasil berbeda diperoleh dalam penelitian Naminingsih \& Rahmayati (2019) yang menemukan bahwa pengakuan profesional tidak berpengaruh signifikan terhadap pemilihan karir akuntan publik karena mendapatkan pengakuan profesionalitas tidak hanya dari menjadi akuntan publik. Indriyarti (2018) juga menemukan hasil bahwa pengakuan profesionalitas tidak berpengaruh pada pemilihan karir, tetapi pemilihan karir dipengaruhi secara signifikan oleh faktor lingkungan kerja.

Lingkungan kerja adalah segala sesuatu yang ada disekitar para pekerja dan dapat memengaruhi dirinya dalam menjalankan tugas-tugas yang dibebankan. Lingkungan kerja dalam akuntan publik lebih dituntut untuk menghadapi tantangan karena jasa yang diberikan oleh klien dapat menimbulkan berbagai macam tekanan kerja untuk mencapai hasil yang sempurna (Daulay, 2016). Penelitian Ari, et al., (2017) menyatakan bahwa lingkungan kerja berpengaruh positif dan signifikan terhadap minat mahasiswa dalam berkarir sebagai akuntan publik. Penelitian Yasa et al., (2019) juga memperoleh hasil bahwa lingkungan keluarga maupun lingkungan kampus, berpengaruh positif baik secara individu maupun bersama-sama terhadap pilihan berkarir di bidang perpajakan. Hasil berbeda diperoleh Kuswidanti (2018) serta Mulianto \& Mangoting (2014) yang menyatakan lingkungan kerja tidak berpengaruh terhadap pilihan karir mahasiswa sebagai akuntan publik dan 
non akuntan publik. Mahasiswa akuntansi yang ingin berkarir sebagai konsultan pajak telah mengetahui lingkungan kerja yang ada di kantor konsultan pajak.

Faktor-faktor yang memengaruhi pemilihan karir dan jenis karir seseorang merupakan hal yang perlu untuk diteliti karena dengan diketahuinya pilihan karir yang diminati, maka dapat diketahui mengapa seseorang memilih karir tersebut. Pemilihan karir seseorang dapat berbeda berdasarkan gender. Gender adalah ciri-ciri yang membedakan pria dan wanita baik secara eksplisit maupun implisit. Secara eksplisit dibedakan secara fisik atau faktor eksternal dan pembedaan secara implisit atau internal seperti sifat, emosi, ketelitian, dan perasaan. Dengan kondisi fisik dan faktor internal, gender akan memengaruhi jenis pekerjaan yang menjadi tujuannya (Lukman \& Juniati, 2017). Berdasarkan penelitian Ari, et al., (2017), gender berpengaruh positif dan signifikan terhadap minat mahasiswa dalam berkarir sebagai akuntan publik. Hasil berbeda didapatkan dari penelitian Lukman \& Juniati (2017) serta Zaid (2015) yaitu gender tidak memiliki pengaruh yang signifikan pada mahasiswa untuk cenderung memilih karir sebagai akuntan publik. Artinya, baik pria maupun wanita sama-sama tidak terdapat perbedaan untuk kecenderungan memilih karir sebagai akuntan publik dan non-akuntan publik. Jadi, probabilitas seorang pria dan wanita untuk memilih menjadi akuntan publik cenderung sama, sehingga dibutuhkan peran orang tua untuk mengarahkan tujuan pemilihan karir seorang anak.

Pelatihan profesional berhubungan dengan Theory of planned behavior, yakni dalam teori ini menyatakan bahwa niat berprilaku individu dimana dalam hal ini adalah minat seseorang dalam pemilihan karir menjadi konsultan pajak dipengaruhi oleh faktor sikap yakni sikap dalam menilai manfaat pelatihan profesional. Sesuai dengan Theory of planned behavior, yaitu semakin positif sikap karyawan tersebut maka akan dapat memengaruhi keputusan karyawan dalam pemilihan karir yang tepat. Jadi apabila karyawan yang bekerja di kantor konsultan pajak LMATS Consulting menilai pelatihan profesional dapat memberi manfaat yang baik, maka akan membentuk sikap positif pada keputusannya dalam pemilihan karir. Melalui pelatihan profesional dapat meningkatkan keahlian, pengetahuan serta dapat mengembangkan sikap dari karyawan. Dengan adanya pelatihan profesional bagi karyawan perusahaan mengharapkan dapat mencapai sasaran kerja yang di inginkan.

Naminingsih \& Rahmayati (2019) menyatakan bahwa pelatihan profesional berpengaruh signifikan terhadap pemilihan karir Akuntan Publik yaitu pelatihan profesional merupakan suatu pembekalan dan peningkatan keahlian yang diberikan oleh suatu organisasi baik bagi calon karyawan ataupun karyawan tetap, dan hal tersebut akan memberikan manfaat secara langsung bagi karyawan dan calon karyawan. Profesi yang memiliki pelatihan profesional yang baik akan menjadi suatu daya tarik bagi profesi tersebut.

Hubungan yang positif antara variabel pelatihan profesional terhadap pemilihan karir juga diperoleh dalam penelitian Indriyarti (2018), Ari, et al., (2017), Mulianto \& Mangoting (2014) yang menyatakan bahwa pelatihan profesional berpengaruh positif dan signifikan terhadap minat mahasiswa dalam berkarir sebagai akuntan publik. Jika pelatihan profesional semakin tinggi, maka minat mahasiswa dalam berkarir sebagai akuntan publik juga semakin tinggi. 
Berlandaskan pada penelitian terdahulu, maka dapat dibentuk rumusan hipotesis sebagai berikut.

$\mathrm{H}_{1}$ : Pelatihan profesional berpengaruh positif terhadap pemilihan karir karyawan LMATS Consulting menjadi konsultan pajak.

Ada kepuasan tersendiri ketika memeroleh pengakuan profesional atau pengakuan prestasi kerjanya, mengingat dibutuhkan keahlian tertentu, waktu yang tidak sebentar dan jenjang karir yang panjang. Dalam penelitian Mulianto \& Mangoting (2014) pengakuan profesional memiliki pengaruh yang signifikan terhadap pemilihan karir mahasiswa akuntansi sebagai konsultan pajak. Pengakuan profesional dapat memengaruhi motivasi kerja karyawan, produktivitas dan kepuasan. Dengan adanya kesempatan untuk berkembang, pengakuan apabila berprestasi dan adanya kenaikan jabatan maka hal tersebut membuat mahasiswa berminat untuk bekerja di kantor konsultan pajak. Penelitian serupa oleh Daulay (2016) juga menemukan hasil bahwa pengakuan profesional berpengaruh terhadap minat menjadi akuntan publik. Hal ini berarti pengakuan profesional dipertimbangkan oleh mahasiswa yang memilih profesi akuntan publik. Hal ini berarti bahwa memilih profesi, tidak hanya bertujuan mencari pengharapan finansial, tetapi juga ada keinginan untuk pengakuan berprestasi dan mengembangkan diri. Berlandaskan pada penelitian terdahulu, maka dapat dibentuk rumusan hipotesis sebagai berikut.

$\mathrm{H}_{2}$ : Pengakuan profesional berpengaruh positif terhadap pemilihan karir karyawan LMATS Consulting menjadi konsultan pajak.

Lingkungan kerja berhubungan dengan Theory of planned behavior, yakni dalam teori ini menyatakan bahwa keyakinan normatif berkaitan langsung dengan pengaruh lingkungan. Lingkungan yang dimaksud adalah lingkungan sosial seperti halnya lingkungan kerja. Karir sebagai konsultan pajak menempatkan individu pada lingkungan kerja yang menyita waktu, tenaga, tingkat persaingan yang ketat, dan banyaknya tekanan untuk menghasilkan pekerjaan yang lebih baik. Sifat pekerjaan, tingkat persaingan dan banyaknya tekanan merupakan faktor lingkungan pekerjaan dan merupakan faktor yang dipertimbangkan dalam pemilihan karir seseorang.

Penelitian Alhadar (2013) memperoleh hasil bahwa lingkungan kerja memiliki pengaruh yang signifikan terhadap pemilihan karier sebagai akuntan publik oleh mahasiswa akuntansi. Menurut Ari, et al., (2017) lingkungan kerja berpengaruh positif dan signifikan terhadap minat mahasiswa dalam berkarir sebagai akuntan publik. Jika lingkungan kerja semakin baik, maka minat mahasiswa dalam berkarir sebagai akuntan publiksemakin tinggi. Berlandaskan pada penelitian terdahulu, maka dapat dibentuk rumusan hipotesis sebagai berikut.

$\mathrm{H}_{3}$ : Lingkungan Kerja berpengaruh positif terhadap pemilihan karir karyawan

LMATS Consulting menjadi konsultan pajak.

Peran Gender berhubungan dengan Theory of planned behavior, yakni dalam teori ini menyatakan bahwa latar belakang (background factors) seperti usia, jenis kelamin, suku, status sosial ekonomi, suasana hati, sifat kepribadian, dan pengetahuan dapat memengaruhi sikap dan perilaku individu terhadap sesuatu hal. Peran gender sangat penting dampaknya dalam tiap aktivitas yang dilakukan oleh manusia, dan dalam hal karir menjadi konsultan pajak ini 
terkadang individu berpandangan bahwa mungkin perempuan kurang cocok menjadi konsultan pajak karena merupakan jenis pekerjaan yang dapat menyita waktu perempuan mengurus keluarganya. Menurut Satoto (2016) suatu kondisi yang menunjukkan kesenjangan laki-laki dan perempuan atau ketimpangan gender, yaitu adanya kesenjangan antara kondisi sebagaimana yang dicitacitakan (kondisi normatif) dengan kondisi gender sebagaimana adanya (kondisi subjektif).

Menurut penelitian Purwati \& Sari (2015) menunjukkan bahwa semakin tinggi persepsi mahasiswa akuntansi mengenai peran gender, maka semakin tingi pula pemilihan karir mahasiswa akuntansi sebagai akuntan. Menurut Ramdani \& Fajar, (2014) yang menyatakan bahwa peran gender memberikan pengaruh yang signifikan terhadap pemilihan karir mahasiswa akuntansi.

Gender adalah ciri-ciri yang membedakan pria dan wanita. Secara ekspilisit dibedakan secara fisik atau faktor eksternal. Namun, pembedaan secara implisit atau internal seperti sifat, emosi, ketelitian, perasaan, dan faktor implisit lainnya juga memberda yang dimiliki seorang pria dan wanita. Dengan kondisi fisik dan faktor internal, gender akan memengaruhi jenis pekerjaan yang menjadi tujuannya (Lukman \& Juniati, 2017). Berdasarkan penelitian Ari, et al., (2017), gender berpengaruh positif dan signifikan terhadap minat mahasiswa dalam berkarir sebagai akuntan publik. Berlandaskan pada penelitian terdahulu, maka dapat dibentuk rumusan hipotesis sebagai berikut.

$\mathrm{H}_{4}$ : Peran gender berpengaruh positif terhadap pemilihan karir karyawan LMATS Consulting menjadi konsultan pajak.

Pengaruh orang tua berhubungan dengan Theory of planned behavior, yakni dalam teori ini menyatakan bahwa keyakinan normatif berkaitan langsung dengan pengaruh lingkungan. Faktor lingkungan yang dimaksud yaitu lingkungan sosial khususnya orang-orang yang berpengaruh bagi kehidupan individu (significant others) dapat memengaruhi keputusan individu. Peran keluarga didalam sosialisasi pra-kerja dilakukan seseorang sebelum memasuki dunia kerja.

Menurut Tyoristi (2015) dukungan orang tua berpengaruh terhadap minat pemilihan karir seorang anak. Penelitian serupa oleh Lukman \& Juniati (2017) serta Mulianto \& Mangoting (2014) juga menyatakan peran orang tua atau parental influence berpengaruh secara signifikan dan positif pada mahasiswa untuk cenderung memilih karir sebagai akuntan publik daripada non akuntan publik. Hal ini disebabkan karena orang yang dianggap penting bagi mahasiswa tidak lain adalah orang tua mereka sendiri. Mahasiswa yang memilih karir sebagai akuntan publik rata-rata menyetujui bahwa pandangan orang tua penting dalam memberikan referensi atau masukan atas karir yang akan dipilih nantinya sedangkan mahasiswa yang memilih karir sebagai non-akuntan publik rata-rata kurang menyetujui bahwa pandangan orang tua penting untuk dijadikan referensi atas pemilihan karirnya nanti. Berlandaskan pada penelitian terdahulu, maka dapat dibentuk rumusan hipotesis sebagai berikut.

$\mathrm{H}_{5}$ : Pengaruh orang tua berpengaruh positif terhadap pemilihan karir karyawan LMATS Consulting menjadi konsultan pajak. 


\section{METODE PENELITIAN}

Penelitian ini dilakukan pada seluruh karyawan/staff di kantor Konsultan Pajak LMATS Consulting. Kantor konsultan pajak LMATS Consulting dipilih karena LMATS Consulting merupakan salah satu kantor konsultan pajak yang cukup besar di bali dimana LMATS Consulting membantu perecanaan karir bagi karyawannya.

Populasi dalam penelitian ini adalah karyawan/staff kantor konsultan pajak LMATS Consulting yang bekerja di divisi keuangan dan divisi pajak yang berjumlah 60 orang. Sampel akan diambil dari populasi tersebut berdasarkan metode purposive sampling.

Teknik analisis yang digunakan dalam penelitian ini adalah teknik analisis data regresi linier berganda (multiple linier regression analysis) yang bertujuan untuk menentukan signifikansi pengaruh pelatihan profesional, pengakuan profesional, lingkungan kerja, lingkungan kerja, peran gender, dan pengaruh orang tua terhadap minat karyawan menjadi konsultan pajak. Adapun model persamaan regresi linier bergandanya sebagai berikut.

$$
Y=\alpha+\beta 1 X 1+\beta 2 X 2+\beta 3 X 3+\beta 4 X 4+\beta 5 X 5+\varepsilon
$$

Keterangan:

$$
\begin{aligned}
& Y=\text { Pemilihan karir sebagai konsultan pajak } \\
& a=\text { Konstanta (nilai } Y \text { apabila nilai } X=0 \text { ) } \\
& \beta 1, \beta 2, \beta 3, \beta 4, \beta 5=\text { Koefisien regresi dari } X \\
& X_{1}=\text { Pelatihan Profesional } \\
& X_{2}=\text { Pengakuan Profesional } \\
& X_{3}=\text { Lingkungan Kerja } \\
& X_{4}=\text { Peran Gender } \\
& X_{5}=\text { Pengaruh Orang Tua } \\
& \varepsilon=\text { Error/Residual }
\end{aligned}
$$

\section{HASIL DAN PEMBAHASAN}

Statistik deskriptif menunjukkan informasi mengenai jumlah pengamatan, nilai minimum, nilai maksimum, nilai mean, dan standar deviasi. Tabel 1, berikut menyajikan hasil statistik deskriptif.

\section{Tabel 1. Hasil Uji Deskriptif}

\begin{tabular}{llllll}
\hline Keterangan & $\mathrm{N}$ & Minimum & Maximum & Mean & $\begin{array}{l}\text { Std. } \\
\text { Deviation }\end{array}$ \\
\hline Pelatihan Profesional & 60 & 8 & 16 & 13.27 & 2.371 \\
Pengakuan Profesional & 60 & 8 & 16 & 12.85 & 2.462 \\
Lingkungan Kerja & 60 & 15 & 28 & 22.43 & 3.811 \\
Peran Gender & 60 & 4 & 12 & 8.45 & 2.541 \\
Pengaruh Orang Tua & 60 & 10 & 20 & 16.15 & 3.007 \\
Presespi Pemilihan Karir & 60 & 8 & 16 & 13.50 & 2.175 \\
Valid N (listwise) & 60 & & & & \\
\hline
\end{tabular}

Sumber: Data Penelitian, 2020

Variabel pelatihan profesional memiliki $\mathrm{N}$ sebesar 60, nilai minimum sebesar 8 dan nilai maksimum sebesar 16, mean sebesar 13,27 dan standar diveviasi sebesar 2,371. Nilai standar deviasi sebesar 2,371 menunjukan bahwa 
nilai standard deviasi lebih kecil dari nilai rata-ratanya. Hal ini mengindikasikan bahwa jawaban responden mengenai pelatihan profesional sudah merata.

Variabel pengakuan profesional memiliki $\mathrm{N}$ sebesar 60, nilai minimum sebesar 8 dan nilai maksimum sebesar 16, mean sebesar 12,85 dan standar diveviasi sebesar 2,462. Nilai standar deviasi sebesar 2,462 menunjukan bahwa nilai standard deviasi lebih kecil dari nilai rata-ratanya. Hal ini mengindikasikan bahwa jawaban responden mengenai pengakuan profesional sudah merata

Variabel lingkungan kerja memiliki $\mathrm{N}$ sebesar 60, nilai minimum sebesar 15 dan nilai maksimum sebesar 28, mean sebesar 22,43 dan standar diveviasi sebesar 3,811. Nilai standar deviasi sebesar 3,811 menunjukan bahwa nilai standard deviasi lebih kecil dari nilai rata-ratanya. Hal ini mengindikasikan bahwa jawaban responden mengenai lingkungan kerja sudah merata

Variabel peran gender memiliki N sebesar 60, nilai minimum sebesar 4 dan nilai maksimum sebesar 12 , mean sebesar 8,45 dan standar diveviasi sebesar 2,541. Nilai standar deviasi sebesar 2,541 menunjukan bahwa nilai standard deviasi lebih kecil dari nilai rata-ratanya. Hal ini mengindikasikan bahwa jawaban responden mengenai peran gender sudah merata

Variabel pengaruh orang tua memiliki $\mathrm{N}$ sebesar 60, nilai minimum sebesar 10 dan nilai maksimum sebesar 20, mean sebesar 16,15 dan standar diveviasi sebesar 3,007. Nilai standar deviasi sebesar 3,007 menunjukan bahwa nilai standard deviasi lebih kecil dari nilai rata-ratanya. Hal ini mengindikasikan bahwa jawaban responden mengenai pengaruh orang tua sudah merata

Variabel presepsi pemilihan karir sebagai konsultan pajak memiliki $\mathrm{N}$ sebesar 60, nilai minimum sebesar 8 dan nilai maksimum sebesar 16, mean sebesar 13,50 dan standar diveviasi sebesar 2,175. Nilai standar deviasi sebesar 2,175 menunjukan bahwa nilai standard deviasi lebih kecil dari nilai rata-ratanya. Hal ini mengindikasikan bahwa jawaban responden mengenai presepsi pemilihan karir sebagai konsultan pajak sudah merata.

\section{Tabel 2. Hasil Analisis Regresi Linier Berganda}

\begin{tabular}{|c|c|c|c|c|c|}
\hline \multirow[t]{2}{*}{ Model } & \multicolumn{2}{|c|}{$\begin{array}{l}\text { Unstandardized } \\
\text { Coefficients }\end{array}$} & \multirow{2}{*}{$\begin{array}{l}\text { Standardized } \\
\text { Coefficients } \\
\text { Beta }\end{array}$} & \multirow[b]{2}{*}{$\mathrm{T}$} & \multirow[b]{2}{*}{ Sig. } \\
\hline & $\mathrm{B}$ & Std. Error & & & \\
\hline (Constant) & 1,030 & 1,023 & & 1,007 & 0,319 \\
\hline Pelatihan Profesional & 0,187 & 0,073 & 0,204 & 2,580 & 0,013 \\
\hline Pengakuan Profesional & 0,232 & 0,094 & 0,263 & 2,479 & 0,016 \\
\hline Lingkungan Kerja & 0,126 & 0,060 & 0,221 & 2,103 & 0,040 \\
\hline Peran Gender & 0,159 & 0,069 & 0,186 & 2,308 & 0,025 \\
\hline Pengaruh Orang Tua & 0,175 & 0,066 & 0,242 & 2,635 & 0,011 \\
\hline $\mathrm{R}$ & 0,872 & & & & \\
\hline R Square & 0,761 & & & & \\
\hline Adjusted R Square & 0,739 & & & & \\
\hline F Statistik & 34,391 & & & & \\
\hline Signifikansi Uji F & 0,000 & & & & \\
\hline
\end{tabular}

Sumber: Data Penelitian, 2020

Koefisien determinasi $\left(\mathrm{R}^{2}\right)$ digunakan untuk mengetahui dan mengukur kemampuan model dalam menerangkan variasi variabel independen. Berdasarkan Tabel 2, nilai Adjust $R$ Square sebesar 0,739, hal ini berarti 73,9 persen variasi pemilihan karir sebagai konsultan pajak (Y) dipengaruhi oleh 
variabel pelatihan profesional $\left(X_{1}\right)$, pengakuan profesional $\left(X_{2}\right)$, lingkungan kerja $\left(X_{3}\right)$ peran gender $\left(X_{4}\right)$ dan pengaruh orang tua $\left(X_{5}\right)$, sisanya sebesar $(100 \%-$ $73,9 \%)=26,1$ persen dipengaruhi oleh faktor lain di luar model.

Berdasarkan hasil analisis regresi pada Tabel 2, variabel independen berpengaruh serempak (simultan) terhadap variabel dependen. Signifikansi $\mathrm{F}$ sebesar 0,000 lebih kecil dari 0,05. Hasil uji $F$ yang di analisis dengan menggunakan program SPSS diperoleh nilai $F_{\text {hitung sebesar 34,391 dengan }}$ signifkansi sebesar 0,000 < 0,05, maka dapat disimpulkan bahwa pada kelompok yang diuji memiliki perbedaan yang nyata (signifikan). Hasil ini mempunyai arti bahwa ada pengaruh signifikan antara pelatihan profesional, pengakuan profesional, lingkungan kerja, peran gender dan pengaruh orang tua terhadap pemilihan karir sebagai konsultan pajak. Dengan demikian, maka model dianggap layak uji dan pembuktian hipotesis dapat dilanjutkan.

Berdasarkan hasil pengujian (uji t) dalam penelitian ini, didapatkan hasil bahwa pelatihan profesional mempunyai nilai koefisien regresi positif sebesar 0,187 dan Sig t 0,013 < 0,050. Hasil pengujian tersebut menunjukkan bahwa hipotesis pertama $\left(\mathrm{H}_{1}\right)$ pelatihan profesional mempunyai pengaruh yang positif terhadap pemilihan karir sebagai konsultan pajak diterima. Hal ini berarti bahwa semakin baik pelatihan profesional maka akan menyebabkan meningkatnya pemilihan karir sebagai konsultan pajak. Berkaitan dengan Theory of Planned Behavior menjelaskan bahwa suatu perilaku akan dilakukan jika individu memiliki keinginan ataupun rencana untuk melakukannya. Semakin kuat keinginan tersebut, maka akan semakin kuat niat tersebut untuk menampilkan suatu perilaku (Jogiyanto, 2017), dimana dalam hal ini adalah minat seseorang dalam pemilihan karir menjadi konsultan pajak dipengaruhi oleh faktor sikap yakni sikap dalam menilai manfaat pelatihan profesional. Sesuai dengan Theory of planned behavior, yaitu semakin positif sikap karyawan tersebut maka akan dapat memengaruhi keputusan karyawan dalam pemilihan karir yang tepat. Jadi apabila karyawan yang bekerja di kantor konsultan pajak LMATS Consulting menilai pelatihan profesional dapat memberi manfaat yang baik, maka akan membentuk sikap positif pada keputusannya dalam pemilihan karir. Melalui pelatihan profesional dapat meningkatkan keahlian, pengetahuan serta dapat mengembangkan sikap dari karyawan. Dengan adanya pelatihan profesional bagi karyawan perusahaan mengharapkan dapat mencapai sasaran kerja yang di inginkan. Hal ini karena Pelatihan Profesional mencakupi hal-hal yang berhubungan dengan peningkatan keahlian. pelatihan profesional meliputi pelatihan sebelum mulai bekerja, pelatihan profesional, pelatihan kerja rutin dan pengalaman kerja. Pelatihan Profesional yang terarah akan meningkatkan minat terhadap karir yang di pilih (Sulistyawati, et al., 2013).

Hasil penelitian ini mendukung hasil penelitian sebelumnya oleh Indriyarti (2018) bahwa pelatihan profesional berpengaruh positif terhadap pemilihan karir sebagai konsultan pajak.

Berdasarkan hasil pengujian (uji t) dalam penelitian ini, didapatkan hasil bahwa pengakuan profesional mempunyai nilai koefisien regresi positif sebesar 0,232 dan Sig t 0,016 < 0,050. Hasil pengujian tersebut menunjukkan bahwa hipotesis kedua $\left(\mathrm{H}_{2}\right)$ pengakuan profesional mempunyai pengaruh yang positif terhadap pemilihan karir sebagai konsultan pajak diterima. Hal ini berarti bahwa 
semakin baik pengakuan profesional yang diperoleh menjadi konsultan pajak maka akan menyebabkan meningkatnya pemilihan karir sebagai konsultan pajak. Berkaitan dengan Theory of Planned Behavior menjelaskan bahwa suatu perilaku akan dilakukan jika individu memiliki keinginan ataupun rencana untuk melakukannya. Semakin kuat keinginan tersebut, maka akan semakin kuat niat tersebut untuk menampilkan suatu perilaku (Jogiyanto, 2017). Sikap karyawan dalam penelitian ini ditunjukkan dengan pengakuan terhadap prestasi. Sesuai dengan Theory of planned behavior, sikap tersebut akan dapat memengaruhi keputusan seseorang dalam pemilihan karir. Dengan diakuinya prestasi kerja akan dapat meningkatkan kualitas pekerjaan yang dihasilkan dan dapat meningkatkan motivasi dalam pencapaian karir yang lebih baik. Pengakuan profesional ini dapat juga dikategorikan sebagai penghargaan yang tidak berwujud finansial Stolle (1976). Elemen-elemen dalam pengakuan profesi meliputi, kesempatan untuk berkembang, pengakuan berprestasi, kesempatan naik pangkat, dan memiliki keahlian tertentu. Dengan adanya pengakuan profesional apabila menjadi seorang konsultan pajak maka nantinya akan meningkatkan pemilihan karir sebagai konsultan pajak, hal ini karena pengakuan profesional merupakan suatu penghargaan yang berwujud nonfinansial yang berhubungan dengan pengakuan terhadap prestasi. Dengan diakuinya prestasi kerja akan dapat meningkatkan kualitas pekerjaan yang dihasilkan dan dapat meningkatkan motivasi dalam pencapaian karir yang lebih baik.

Hasil penelitian ini didukung oleh hasil penelitian sebelumnya oleh Mulianto \& Mangoting (2014) bahwa pengakuan profesional berpengaruh positif terhadap pemilihan karir sebagai konsultan pajak.

Berdasarkan hasil pengujian (uji t) dalam penelitian ini, didapatkan hasil bahwa lingkungan kerja mempunyai nilai koefisien regresi positif sebesar 0,126 dan Sig t 0,040 < 0,050. Hasil pengujian tersebut menunjukkan bahwa hipotesis ketiga $\left(\mathrm{H}_{3}\right)$ lingkungan kerja mempunyai pengaruh yang positif terhadap pemilihan karir sebagai konsultan pajak diterima. Hal ini berarti bahwa semakin baik lingkungan tempat bekerja apabila menjadi konsultan pajak maka akan menyebabkan meningkatnya pemilihan karir sebagai konsultan pajak. Berkaitan dengan Theory of Planned Behavior menjelaskan bahwa suatu perilaku akan dilakukan jika individu memiliki keinginan ataupun rencana untuk melakukannya. Semakin kuat keinginan tersebut, maka akan semakin kuat niat tersebut untuk menampilkan suatu perilaku (Jogiyanto, 2017). Lingkungan kerja berhubungan dengan Theory of planned behavior, yakni dalam teori ini menyatakan bahwa keyakinan normatif berkaitan langsung dengan pengaruh lingkungan. Lingkungan yang dimaksud adalah lingkungan sosial seperti halnya lingkungan kerja. Karir sebagai konsultan pajak menempatkan individu pada lingkungan kerja yang menyita waktu, tenaga, tingkat persaingan yang ketat, dan banyaknya tekanan untuk menghasilkan pekerjaan yang lebih baik. Sifat pekerjaan, tingkat persaingan dan banyaknya tekanan merupakan faktor lingkungan pekerjaan dan merupakan faktor yang dipertimbangkan dalam pemilihan karir seseorang. Dengan adanya lingkungan kerja yang baik serta nyaman apabila menjadi konsultan pajak maka nantinya akan meningkatkan pemilihan karir sebagai konsultan pajak, hal ini karena lingkungan kerja adalah 
sesuatu yang ada disekitar para pekerja dan yang memengaruhi dirinya dalam menjalankan tugas-tugas yang dibebankan (Nitisemito, 2000:25)

Hasil penelitian ini didukung oleh hasil penelitian sebelumnya oleh Ari, et al., (2017) bahwa lingkungan kerja berpengaruh positif terhadap pemilihan karir sebagai konsultan pajak.

Berdasarkan hasil pengujian (uji t) dalam penelitian ini, didapatkan hasil bahwa peran gender mempunyai nilai koefisien regresi positif sebesar 0,159 dan Sig t 0,025 < 0,050. Hasil pengujian tersebut menunjukkan bahwa hipotesis keempat $\left(\mathrm{H}_{4}\right)$ peran gender mempunyai pengaruh yang positif terhadap pemilihan karir sebagai konsultan pajak diterima. Hal ini berarti bahwa semakin baik peran gender maka akan menyebabkan meningkatnya pemilihan karir sebagai konsultan pajak. Berkaitan dengan Theory of Planned Behavior menjelaskan bahwa suatu perilaku akan dilakukan jika individu memiliki keinginan ataupun rencana untuk melakukannya. Semakin kuat keinginan tersebut, maka akan semakin kuat niat tersebut untuk menampilkan suatu perilaku (Jogiyanto (2017). Peran Gender berhubungan dengan Theory of planned behavior, yakni dalam teori ini menyatakan bahwa latar belakang (background factors) seperti usia, jenis kelamin, suku, status sosial ekonomi, suasana hati, sifat kepribadian, dan pengetahuan dapat memengaruhi sikap dan perilaku individu terhadap sesuatu hal. Peran gender sangat penting dampaknya dalam tiap aktivitas yang dilakukan oleh manusia, dan dalam hal karir menjadi konsultan pajak ini terkadang individu berpandangan bahwa mungkin perempuan kurang cocok menjadi konsultan pajak karena merupakan jenis pekerjaan yang dapat menyita waktu perempuan mengurus keluarganya. Dengan adanya kesetaraan gender atau tidak membedakan pria atau wanita dalam pekerjaan di konsultan pajak akan meningkatkan pemilihan karir menjadi konsultan pajak.

Hasil penelitian ini didukung oleh hasil penelitian sebelumnya oleh Ramdani \& Fajar (2014) bahwa peran gender berpengaruh positif terhadap pemilihan karir sebagai konsultan pajak.

Berdasarkan hasil pengujian (uji t) dalam penelitian ini, didapatkan hasil bahwa pengaruh orang tua mempunyai nilai koefisien regresi positif sebesar 0,175 dan Sig t 0,011 < 0,050. Hasil pengujian tersebut menunjukkan bahwa hipotesis kelima $\left(\mathrm{H}_{5}\right)$ pengaruh orang tua mempunyai pengaruh yang positif terhadap pemilihan karir sebagai konsultan pajak diterima. Hal ini berarti bahwa semakin kuat pengaruh orang tua maka akan menyebabkan meningkatnya pemilihan karir sebagai konsultan pajak. Berkaitan dengan Theory of Planned Behavior menjelaskan bahwa suatu perilaku akan dilakukan jika individu memiliki keinginan ataupun rencana untuk melakukannya. Semakin kuat keinginan tersebut, maka akan semakin kuat niat tersebut untuk menampilkan suatu perilaku (Jogiyanto, 2017). Pengaruh orang tua berhubungan dengan Theory of planned behavior, yakni dalam teori ini menyatakan bahwa keyakinan normatif berkaitan langsung dengan pengaruh lingkungan. Faktor lingkungan yang dimaksud yaitu lingkungan sosial khususnya orang-orang yang berpengaruh bagi kehidupan individu (significant others) dapat memengaruhi keputusan individu. Peran keluarga didalam sosialisasi pra-kerja dilakukan seseorang sebelum memasuki dunia kerja. Dengan adanya dorongan dari orang 
tua kepada anaknya untuk menjadi konsultan pajak, akan meningkatkan pemlihan karir menjadi konsultan pajak.

Hasil penelitian ini didukung oleh hasil penelitian sebelumnya oleh Mulianto dan Mangoting (2014) bahwa pengaruh orang tua berpengaruh positif terhadap pemilihan karir sebagai konsultan pajak.

\section{SIMPULAN}

Penelitian yang dilakukan diharapkan dapat memberikan hasil mengenai analisis faktor-faktor yang mempengaruhi pemilihan karir sebagai konsultan pajak di kantor konsultan pajak LMATS Consulting. Hasil uji hipotesis dalam penelitian ini ditemukan bahwa secara statistik pelatihan profesional, pengakuan profesional, lingkungan kerja, peran gender dan dukungan orang tua berpengaruh positif terhadap pemilihan karir sebagai konsultan pajak, sehingga hal tersebut sesuai dengan kajian penelitian terdahulu dan sesuai dengan Theory of Planned Behavior menjelaskan bahwa suatu perilaku akan dilakukan jika individu memiliki keinginan ataupun rencana untuk melakukannya. Semakin kuat keinginan tersebut, maka akan semakin kuat niat tersebut untuk menampilkan suatu perilaku.

Penelitian ini memberikan implikasi bagi LMATS Consulting sebagai pertimbangan dan pengetahuan mengenai pemilihan karir sebagai konsultan pajak serta faktor-faktor yang memengaruhinya LMATS Consulting dapat mengevaluasi pelatihan profesional, pengakuan profesional, lingkungan kerja, peran gender dan dukungan orang tua, karena hal tersebut dapat mempengaruhi pemilihan karir sebagai konsultan pajak.

\section{REFERENSI}

Alhadar, M. . (2013). Faktor-Faktor yang Memengaruhi Pemilihan Karir sebagai Akuntan Publik. (Skripsi). Universitas Hasanuddin. Makassar. 2013.

Ari, K. B. J., Wahyuni, M. A., \& Sulindawati, N. L. G. E. (2017). Pengaruh Faktor Gender, Pertimbangan Pasar Kerja, Lingkungan Kerja, Penghargaan Finansial dan Pelatihan Profesional Terhadap Minat Mahasiswa dalam Berkarir sebagai Akuntan Publik. E-JournalS1 Ak Universitas Pendidikan Ganesha, 8(2).

Daulay, M. (2016). Faktor-Faktor Yang Mempengaruhi Pemilihan Karir Mahasisa Akuntansi Sebagai Akuntan Publik. Journal of Chemical Information and Modeling. https:// doi.org/10.1017/CBO9781107415324.004

Indriyarti, E. R. (2018). Pemahaman Mahasiswa Mengenai Peluang Usaha Jasa Konsultan Pajak Dan Faktor-Faktor Yang Memengaruhinya. Jurnal Pengabdian Dan Kewirausahaan, 2(1), 68-80.

Kuswidanti, H. A. (2018). Analisis Faktor-Faktor Yang Mempengaruhi Pemilihan Karir Menjadi Akuntan Publik (Studi Empiris pada Mahasiswa Fakultas Ekonomi dan Bisnis Jurusan Akuntansi Universitas Muhammadiyah Surakarta). Jurnal Akuntansi Dan Keuangan, 2, 1-32.

Lukman, H., \& Juniati, C. (2017). Faktor Yang Pengaruhi Pemilihan Karir Sebagai Akuntan Publik Bagi Mahasiswa Pts Wasta Dengan Pendekatan Reasoned Action Model. Jurnal Akuntansi, 20(2), 202. https://doi.org/10.24912/ja.v20i2.54 
Merdekawati, D. P., \& Sulistyawati, A. I. K. A. (2011). Faktor-Faktor yang Mempengaruhi Pemilihan Karir Akuntan Publik dan Non Akuntan Publik. 13(1), 9-19.

Mulianto, S. F., \& Mangoting, Y. (2014). Faktor - Faktor Yang Mempengaruhi Pilihan Karir Mahasiswa Akuntansi Sebagai Konsultan Pajak. Tax E Accounting Review, 4(2).

Naminingsih, N. N., \& Rahmayati, A. (2019). Faktor-Faktor yang Mempengaruhi Dalam Pemilihan Karir Akuntnasi Publik. Seminar Nasional Dan The 6th Call for Syariah Paper.

Purwati, A. S., \& Sari, Y. Y. (2015). Persepsi Mahasiswa Akuntansi Terhadap Pemilihan Karier. Jurnal FEB Unsoed, 5.

Ramdani, Rahmat Fajar, Z. (2014). Analisis Faktor-Faktor Yang Mempengaruhi Pemilihan Karir Mahasiswa Akuntansi. Diponegoro Journal Of Accounting, 2(4).

Stolle, S. . (1976). Student's View of The Public and Industrial Accountant. Jurnal of Accountancy.

Sulistyawati, Adriani Ika, Nina Ernawati, dan S. N. (2013). Persepsi Mahasiswaa Akuntansi Mengenai Faktor-Faktor Yang Mempengaruhi Pemilihan Karir. 5(2), 86-98.

Tyoristi, N. (2015). Pengaruh Dukungan Orang Tua Terhadap Minat Siswa Laki-Laki Untuk Memilih Dan Belajar Di Sekolah Dengan Program Keahlian Jasa Boga Dan Patiseri Di Smk Pius X Magelang.

Yasa, I Nyoman Putra, I.A Gede Danika Esa Pradnyani, A. T. A. (2019). Peran Lingkungan, Pertimbangan Pasar Kerja dan Persepsi Mahasiswa Berkarir di Bidang Perpajakan. 11(1), 81-89.

Yuniharisa. (2014). Persepsi Mahasiswa Akuntansi Mengenai Faktor-Faktor Yang Membedakan Pemilihan Karir Sebagai Akuntan.

Zaid, M. I. (2015). Pengaruh Gender, Penghargaan Finansial, Dan Pertimbangan Pasar Kerja Terhadap Minat Mahasiswa Akuntansi Untuk Berkarier Menjadi Akuntan Publik. 